doi: dx.doi.org/10.24866/1560-8425/2020-24/61-66

2020, vol. 24, N 1/2, pp. 61-66

\title{
New finding of the epitoniid Cirsotrema matugisiense (Ozaki, 1958) (Mollusca: Gastropoda) in the Sea of Japan
}

\author{
Boris I. Sirenko ${ }^{1}$, Evgeny N. Drobyazin ${ }^{2}$ \\ ${ }^{1}$ Zoological Institute, Russian Academy of Sciences, St. Petersburg 199034, Russia \\ e-mail:marine@zin.ru \\ ${ }^{2}$ Pacific Branch of the Russian Federal Research Institute of Fisheries \\ and Oceanography («TINRO»), Vladivostok 690950, Russia \\ e-mail: eugeny999@mail.ru
}

\begin{abstract}
We describe a new finding of Cirsotrema matugisiense (Ozaki, 1958) from the northern Sea of Japan. This species differs from the other species of the family Epitoniidae having few low, flattened, wide spiral ribs throughout the whole surface of each whorl excluding the base. Most similar to C. matugisiense is Amaea iwaotakii Azuma, 1961 which differs from the former in having the whorls with many distinct minute spiral striae except on the upper third of each whorl (vs. a few low, flattened, wide spiral ribs throughout the whole surface of each whorl excluding the base in C. matugisiense); all axial ribs are rather similar in size (vs. the axial ribs of different thickness, especially on the last whorl in C. matugisiense).
\end{abstract}

Key words: Gastropoda, Epitoniidae, Cirsotrema, Sakhalin, Sea of Japan.

\section{Новая находка эпитонииды Cirsotrema matugisiense (Ozaki, 1958) (Mollusca: Gastropoda) в Японском море}

Б.И. Сиренко ${ }^{1}$, Е.Н. Дробязин ${ }^{2}$

'Зоологический институт РАН, С.-Петербург 199034, Россия e-mail: marine@zin.ru

${ }^{2}$ Тихоокеанский филиал Всероссийского научно-исследовательского института рыбного хозяйства и океанографии («ТИНРО»), Владивосток 690950, Россия e-mail: eugeny999@mail.ru

Описана новая находка гастроподы Cirsotrema matugisiense (Ozaki, 1958) из Японского моря. Этот вид хорошо отличается от других видов семейства Epitoniidae наличием 6 низких, уплощенных, широких спиральных ребер на всей поверхности каждого оборота, исключая основание. Наиболее сходным с C. matugisiense видом является Amaea iwaotakii Azuma, 1961, который отличается от него наличием оборотов раковины с многими отчетливыми, мелкими спиральными бороздками за исключением верхней 1/3 каждого оборота (несколько низких, уплощенных, широких спиральных ребер на всей поверхности каждого оборота, исключая основание у C. matugisiense); все осевые ребра довольно сходны по размеру (осевые ребра различной толщины особенно на последнем обороте у C. matugisiense).

Ключевые слова: Gastropoda, Epitoniidae, Cirsotrema, Сахалин, Японское море. 
Gastropods of the family Epitoniidae inhabit mainly warm waters. This is especially evident when comparing the epitoniid faunas of two regions the Far Eastern seas of Russia and Japan. In the first region which occupies a huge part of the Pacific Ocean, only 8 species are found [Sirenko et al., 2013], while in the second region, which is much smaller than the first one, there are 116 species [Tsuchida, 2000], 130 species [Higo et al., 1999] or 164 species [Nakayama, 2003]. In addition, a significant number of species of the latter region mainly inhabit the southern part of Honshu Island and further south [Tsuchida, 2000]. We are adding a newly found species collected near western Sakhalin to this small group of epitoniids inhabiting Northern Pacific.

\section{Material and methods}

Four specimens examined herein were collected during the cruise of R/V Bukhoro, by E. Drobyazin and I. Kornejchuk near Sakhalin in 2015 and 2018. The specimens were caught alive, but later the bodies were not kept. The taxonomic arrangement follows Bouchet et al. [2017]. The photographs were taken by the camera Cannon G7.

Abbreviations: FEFU, Zoological Museum of the Far Eastern Federal University, Vladivostok, Russian Federation; NSCMB FEB RAS, A.V. Zhirmunsky National Scientific Center of Marine Biology, Far Eastern Branch of the Russian Academy of Sciences, Vladivostok, Russian Federation; NSMT, National Museum of Nature and Science, Tsukuba, Japan; TINRO, Pacific Institute of Fisheries and Oceanography (a branch of VNIRO); VNIRO, Russian Federal Research Institute of Fisheries and Oceanography, Vladivostok, Russian Federation; ZISP, Zoological Institute, Russian Academy of Sciences, St. Petersburg, Russian Federation.

\section{Taxonomy}

Class GASTROPODA Cuvier, 1795

Subclass CAENOGASTROPODA Cox, 1960

Grade ARCHITAENIOGLOSSA Haller, 1890

Cohort SORBEOCONCHA Ponder et Lindberg, 1997

Subcohort HYPSOGASTROPODA Ponder et Lindberg, 1997

Superfamily Epitonioidea Berry, 1910

Family Epitoniidae Berry, 1910

Genus Cirsotrema Mörch, 1852

Cirsotrema matugisiense (Ozaki, 1958)

Figs. 1, 2B-F

Epitonium (Boreoscala) matugisiensis Ozaki, 1958, p. 142, pl. 15, fig. 25 (fossil); Brown, Neville, 2015, p. 102 (fossil and Recent).

Epitonium (Boreoscala) yokozunai Ozaki, 1958, p. 143, pl. 15, fig. 26 (fide Nakayama [2003]) (fossil). Cirsotrema matugisiense (Ozaki, 1958): Nakayama, 2003, p. 29, pl. 4, figs. $23-27$ (fossil and Recent); Tsushida, Hasegawa, 2017, p. 894, pl. 183, fig. 7 (fossil and Recent). 


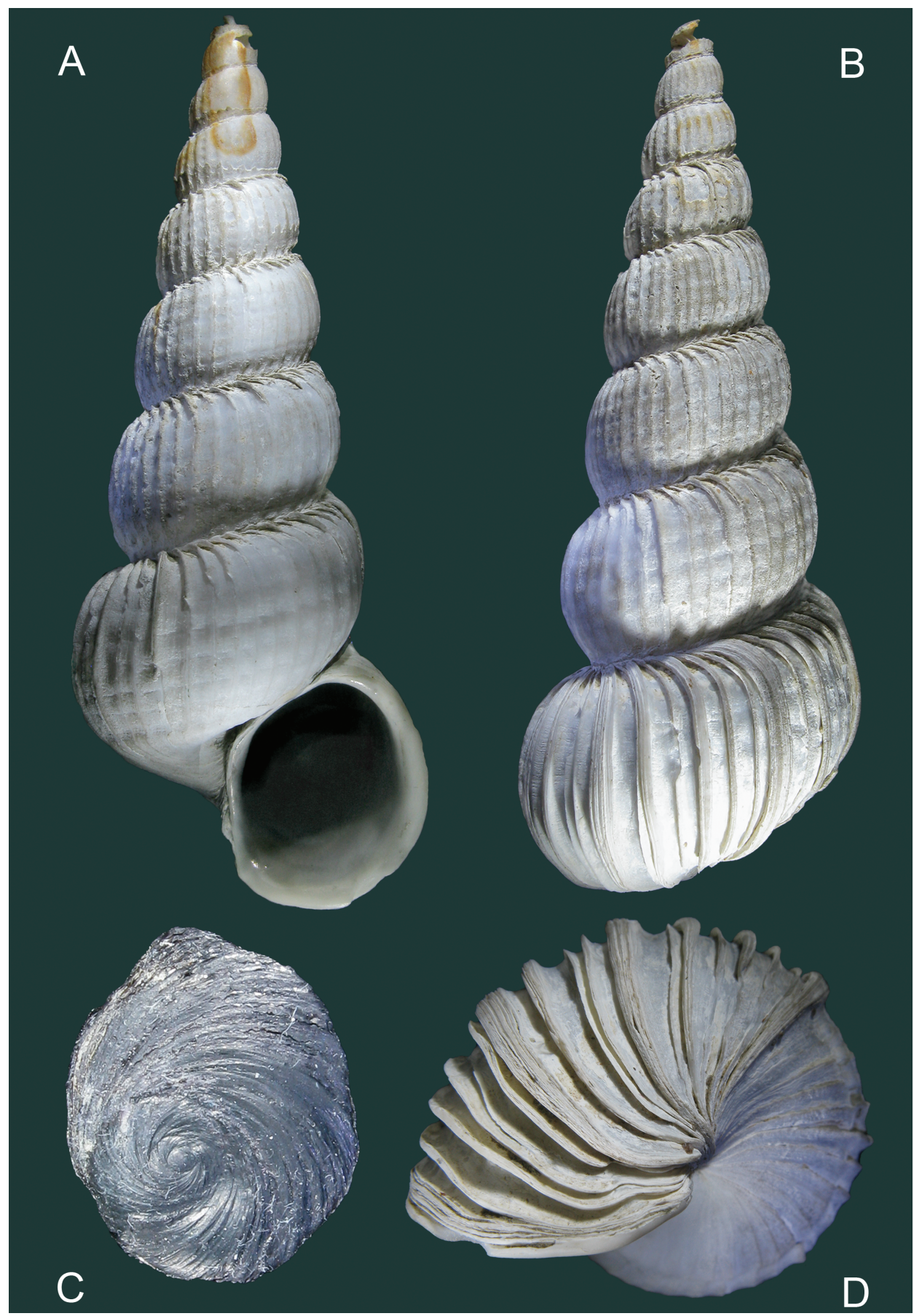

Fig. 1. Cirsotrema matugisiense, A-C - specimen ZISP 62489/1, shell, height of shell $83.1 \mathrm{~mm}$, diameter of the last whorl $34.0 \mathrm{~mm}$; D - specimen ZISP 62490/2, operculum 17.1x13.9 mm. 


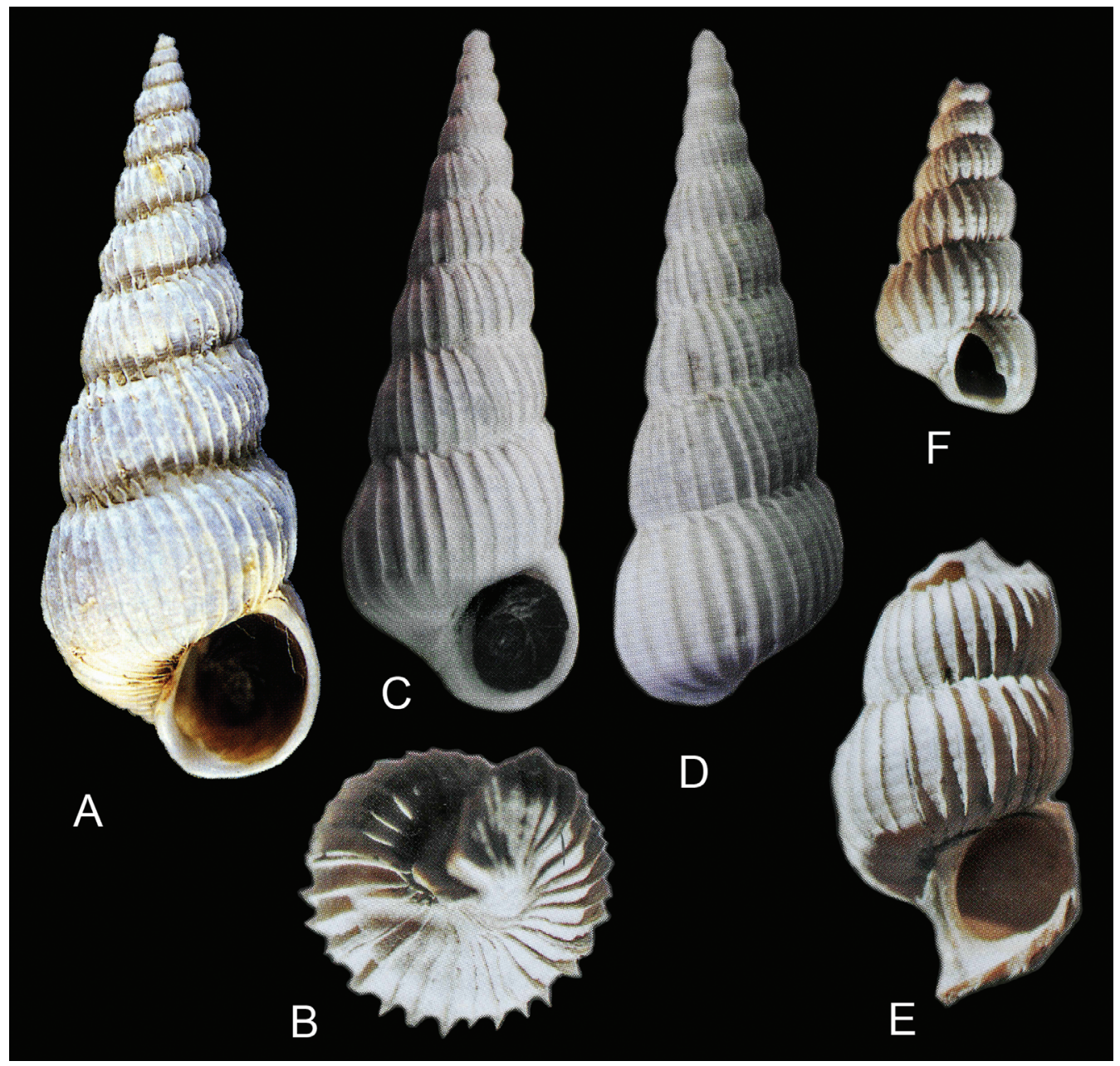

Fig. 2. Shells of Epitoniidae: A - Amaea iwaotakii, after Tsushida [2000]; C, D - Cirsotrema matugisiense (Recent), after Nakayama [2003]; B, E - Epitonium (Boreoscala) yokozunai (the holotype, fossil, after Nakayama [2003]); F - Epitonium (Boreoscala) matugisiense (the holotype, fossil, after Nakayama [2003]).

Type material. The holotype (NSMT 4498).

Ty p e 1 o c a lity. Cliff, 500 m south of Matugisi Railway Station, Tyosi City, Iioka Formation, Neogene.

Material examined. The Sea of Japan, near western Sakhalin, 47 $16.4^{\prime}-$ $47^{\circ} 15.9^{\prime} \mathrm{N}, 141^{\circ} 47.3^{\prime}-141^{\circ} 47.0^{\prime} \mathrm{E}$, depth 386-388 m, mud, R/V Bukhoro, research trawl, 2 specimens (ZISP 62489); 1 specimen (FEFU XII 53121/Ga-10171), 04.07.2018, coll. E.N. Drobyazin; $47^{\circ} 16.5^{\prime}-47^{\circ} 15.9^{\prime} \mathrm{N}, 141^{\circ} 45.2^{\prime}-141^{\circ} 44.6^{\prime} \mathrm{E}$, depth $521 \mathrm{~m}$, mud, R/V Bukhoro, research trawl, 1 specimen, 28.05.07.2015, coll. I. Kornejchuk. 
D istribution. Japan: Boso Peninsula (fossil) [Nakayama, 2003; Tsuchida, Hasegawa, 2017], off Kunashir Island, Hokkaido, Japan [Nakayama, 2003] and the Sea of Japan, near western Sakhalin (this study). Nakayama [2003] was the first to report the discovery of this species in the Recent fauna near Kunashir Id. and Hokkaido. Unfortunately he did not give more detailed information about locality and depths. Specimens collected from western Sakhalin significantly advance the boundaries of the area of this species to the north and are the first find of the species off the coast of Russia. Reports of the distribution of this species off Greenland and in the Arctic seas [Tsuchida, 2000], appear to be associated with incorrect identifications. Kazunori Hasegawa (in e-mail message) informed that he has seen specimens of this species only from the north-western Pacific (eastern Hokkaido and northwards), Okhotsk Sea and northern Sea of Japan.

Due to some differences between western Sakhalin specimens and fossil type and other similar specimens, we found it useful to give a brief description and distinctive diagnosis.

Description. Shell big for the genus, height up to $85.4 \mathrm{~mm}$, high, thin but rather solid, grayish white. Protoconch damaged, teleoconch consist of 7 convex whorls separated by distinct narrow sutures. Axial sculpture of teleoconch whorls consisting of numerous, low ribs of different thickness especially on the last whorl, where there are 36 axial ribs. Spiral ribs rather low, flattened, wide, 6 spiral ribs on whole surface of each whorl excluding base. Axial and spiral ribs presenting weakly cancellated appearance. Umbilicus narrow, fissure-like. Aperture round, the outer edge of the aperture is thickened by a wide axial rib, columellar lip narrow, smooth, slightly erect, the inner surface of the aperture purple. Operculum brownish black, paucispiral, nucleus of operculum shifted to the lower left edge.

There is no information about the radula due to the lack of soft parts of the body.

$\mathrm{R} \mathrm{e} \mathrm{m} \mathrm{a} \mathrm{rks.} \mathrm{The} \mathrm{protoconchs} \mathrm{of} \mathrm{all} \mathrm{studied} \mathrm{specimens} \mathrm{were} \mathrm{destroyed,} \mathrm{so} \mathrm{the} \mathrm{real}$ height of the shell is a few millimeters more (see Table). Nakayama [2003] believes that the holotypes of Epitonium (Boreoscala) matugisiense Ozuka, 1958 (Fig. 2F) and E. (B). yokozunai Ozuki, 1958 (Fig. 2B, E) are two parts of the same shell, so he composed the characters. According to the new diagnosis, the holotype of $C$. matugisiense has 26 axial ribs and 9 spiral ribs, which is at odds with the number of ribs in western Sakhalin

Measurements of different parameters of shells of studied specimens

\begin{tabular}{lccc}
\hline \multicolumn{1}{c}{ Parameters of shell } & $\begin{array}{c}\text { Specimen } \\
\text { (ZISP 62489/1) }\end{array}$ & $\begin{array}{c}\text { Specimen } \\
\text { (ZISP 62489/2) }\end{array}$ & $\begin{array}{c}\text { Specimen } \\
\text { (FEFU XII 53121/Ga-10171) }\end{array}$ \\
\hline Height of shell & $83.1 \mathrm{~mm}$ & $72.0 \mathrm{~mm}$ & $85.4 \mathrm{~mm}$ \\
Diameter of last whorl & $34.0 \mathrm{~mm}$ & $31.1 \mathrm{~mm}$ & $34.0 \mathrm{~mm}$ \\
Height of last whorl & $36.7 \mathrm{~mm}$ & $36.6 \mathrm{~mm}$ & $37.1 \mathrm{~mm}$ \\
Height of aperture & $22.6 \mathrm{~mm}$ & $22.1 \mathrm{~mm}$ & $23.5 \mathrm{~mm}$ \\
Width of aperture & $18.1 \mathrm{~mm}$ & $17.9 \mathrm{~mm}$ & $18.5 \mathrm{~mm}$ \\
\hline
\end{tabular}


specimens. In addition, the last specimens have a slit-like umbilicus. Kasunori Hasegawa (in e-mail message) and we believe that this is the result of intraspecific variability.

C. matugisiense differs from the other species of the family Epitoniidae, having few low flattened, wide spiral ribs throughout the whole surface of each whorl, excluding the base. Most similar to C. matugisiense is Amaea iwaotakii Azuma, 1961 (Fig. 2A). A. iwaotakii differs from C. matugisiense in having the whorls with many distinct minute spiral striae except on the upper third of each whorl [Azuma, 1961] (vs. a few low flattened, wide spiral ribs throughout the whole surface of each whorl excluding the base in C. matugisiense); all axial ribs are rather similar in size (vs. the axial ribs of different thickness, especially on the last whorl, in C. matugisiense).

\section{Acknowledgements}

We would like to thank Sergei Yavnov (TINRO) and Ilja Kornejchuk (TINRO) who gave us the opportunity to examine this species, Kazunori Hasegawa (NSMT), Vladimir Gulbin (NSCMB FEB RAS) and anonymous reviewer for their very important comments, Mihael Blikshteyn (Portland, Oregon, U.S.A.) for polishing English, Galina Kuznetsova (ZISP), who prepared the digital plates. This study was performed using equipment of the «Taxon» Research Resource Center (http://www.ckp-rf.ru/ckp/ 3038/?sphrase id=8879024) of the Zoological Institute, Russian Academy of Sciences (St. Petersburg). This work was supported by the State Scientific Program «Taxonomy, Biodiversity and Ecology of Invertebrates from Russian and Adjacent Waters of the World Ocean, Continental Water Bodies and Damped Areas» (AAAA-A19-119020690072-9).

\section{References}

Azuma M. 1961. Description of six new species of Japanese marine Gastropoda // Venus. V. 21, N 3. P. 296-303.

Bouchet P., Rocroi J.-P., Hausdorf B., Kaim A., Kano Y., Nützel A., Parkhaev P., Schrödl M., Strong E.E. 2017. Revised classification, nomenclator and typification of gastropod and monoplacophoran families // Malacologia. V. 61, N 1-2. P. 1-526.

Brown L.G., Neville B.D. 2015. Catalog of the recent taxa of the families Epitoniidae and Nystiellidae (Mollusca: Gastropoda) with a bibliography of the descriptive and systematic literature // Zootaxa. V. 3907, N 1. P. $1-188$.

Higo S., Callomon P., Goto Y. 1999. Catalogue and Bibliography of the Marine Shell-bearing Mollusca of Japan. Gastropoda, Bivalvia, Polyplacophora, Scaphopoda. Osaka: Elle Scientific Publications. 749 p.

Nakayama T. 2003. A review of Northwest Pacific epitoniids (Gastropoda: Epitoniidae) // Monographs of Marine Mollusca. V. 6. P. 1-143.

Sirenko B.I., Kantor Yu.I., Gulbin V.V. 2013. Clade Ptenoglossa // Check-list of Species of Free-living Invertebrates of the Russian Far Eastern Seas. B.I. Sirenko (Ed). St. Petersburg: Zoological Institute, Russian Academy of Sciences. P. 156. [Explorations of the Fauna of the Seas. V. 75(83)].

Tsuchida E. 2000. Family Epitoniidae // Marine Mollusks in Japan. Okutani T. (Ed). Tokyo: Tokai University Press. P. $320-343$.

Tsuchida E., Hasegawa K. 2017. Family Epitoniidae // Marine Mollusks in Japan. Okutani T. (Ed.). The Second Edition. Hiratsuka: Tokai University Press. P. 223-234 (plates), 889-901 (text).

Published online December 25, 2020 